\section{Nematode Control from Shank- and Drip-applied Fumigant Alternatives to Methyl Bromide}

\author{
Sally M. Schneider \\ National Program Staff, USDA-ARS, Beltsville, MD 20705-5139
}

Husein A. Ajwa
Department of Plant Sciences, University of California, Davis, Salinas,
CA 93905

Thomas J. Trout

Water Management Research Unit, USDA-ARS, Fort Collins, CO 80526-8119

\author{
Suduan Gao ${ }^{1}$ \\ San Joaquin Valley Agricultural Sciences Center, USDA-ARS, 9611 South \\ Riverbend Avenue, Parlier, CA 93648
}

Additional index words. drip fumigation, shank fumigation, nursery

\begin{abstract}
Field studies were conducted to evaluate potential alternatives to methyl bromide (MBr) for the control of plant parasitic nematodes in shallow-rooted, bedded cropping systems such as strawberry and in perennial nursery cropping systems in central California. Chloropicrin (Pic), 1,3-dichloropropene (1,3-D or Telone), combinations of 1,3-D + Pic, iodomethane (IM) + Pic, propargyl bromide (PBr), and metam sodium (MS) were compared with untreated controls and industry standard $\mathrm{MBr} / \mathrm{Pic}$ treatments. Materials were applied by both shank-injection and drip-application, except MS and $\mathrm{PBr}$, which were applied only by drip. The efficacy on citrus nematode (Tylenchulus semipenetrans Cobb) and/or root-knot nematode (Meloidogyne spp. Chitwood) control was investigated in three trials conducted on soils ranging from sandy loam to silty clay loam. All treatments controlled nematodes near the injection point (center of bed and moderate depths) comparable to $\mathrm{MBr} / \mathrm{Pic}$. Drip-applied Pic provided somewhat less control than $\mathrm{MBr} / \mathrm{Pic}$ at the shoulder of the bed when delivered in $25 \mathrm{~mm}$ of water and MS provided no control at the bed shoulder. IM + Pic, both shank-injected and dripapplied, provided nematode control to a depth of $150 \mathrm{~cm}$ comparable to $\mathrm{MBr} / \mathrm{Pic}$. Telone EC applied to a dry field in $75 \mathrm{~mm}$ water did not control nematodes well at either 90- or 150-cm depths, whereas $\mathrm{PBr}$ controlled nematodes as effectively as $\mathrm{MBr} / \mathrm{Pic}$ at the $90-\mathrm{cm}$ depth, but not at the $150-\mathrm{cm}$ depth. Propargyl bromide at $67 \mathrm{~kg} \cdot \mathrm{ha}^{-1}$ was effective at killing the nematodes up to $30 \mathrm{~cm}$ deep in a strawberry plant bed. The dosage exposure values (within $96 \mathrm{~h}$ after fumigation) observed for greater than $99 \%$ control of nematodes were much lower for $\operatorname{PBr}\left(\approx 1 \mathrm{mg} \cdot \mathrm{L}^{-1} \cdot \mathrm{h}\right)$ than those for $1,3-\mathrm{D}+\operatorname{Pic}\left(17 \mathrm{mg} \cdot \mathrm{L}^{-1} \cdot \mathrm{h}\right.$ when applied at 61:35 1,3-D:Pic mass ratio), Pic alone $\left(10 \mathrm{mg} \cdot \mathrm{L}^{-1} \cdot \mathrm{h}\right)$, and IM + Pic $\left(19 \mathrm{mg} \cdot \mathrm{L}^{-1} \cdot \mathrm{h}\right.$ when applied at 50:50 mass ratio). Drip application technology showed promise for effective alternatives to $\mathrm{MBr} / \mathrm{Pic}$. Consistent delivery of an effective dosage of a material throughout the target soil profile is necessary for consideration as an acceptable alternative to $\mathrm{MBr}$ for high-value crops.
\end{abstract}

Soil fumigation with methyl bromide/ chloropicrin $(\mathrm{MBr} / \mathrm{Pic})$ is the standard for soil disinfestations and is used to reduce the risk of yield loss resulting from soilborne pathogens in high-value crops such as strawberry and in certified field nurseries to meet clean propagative material regulations [California Dept. of Food and Agriculture (CDFA), 2002]. MBr/Pic can effectively control soil pests over a range of soil types, temperatures, and moistures resulting in greater flexibility of use and less risk of loss than is possible with many other soil treatments. $\mathrm{MBr}$ was identified as an ozone- depleting substance and was banned for use as a soil fumigant in the United States as of Jan. 2005 (with exceptions) under the provisions of the U.S. Clean Air Act and the Montreal Protocol (U.S. Environmental Protection Agency, 2008). While seeking temporary critical use exemptions for $\mathrm{MBr}$, growers continued to search for alternatives to continue to produce clean berry, vine, and tree propagative material and to meet high yield and quality expectations. To be an acceptable management strategy, an alternative must be effective, available, and economically feasible with minimal negative impact to the environment. Documentation of efficacy for certified nursery use in California must be evaluated and accepted by the appropriate regulatory bodies. If the efficacy of a treatment is accepted, it can be added to CDFA's “Approved Treatment and Handling Procedures to Ensure Against Nematode Pest Infestation of Nursery Stock" (CDFA, 2002).

The search for alternative chemical treatments has included evaluation of new or old materials and alternative application methods for currently registered or nonregistered fumigants that have potential to be alternatives to $\mathrm{MBr}$. Metam sodium (MS), 1,3dichloropropene (1,3-D), and Pic are currently registered in the United States and have provided nematode, pathogen, or weed control in trials in various production systems (DeCal et al., 2004; Gilreath et al., 2005; Karlik et al., 2001; Mann et al., 2005; Stanghellini et al., 2003). Nematode contol results in the literature with drip-applied MS are inconsistent (Overman, 1982; Overman et al., 1987; Roberts et al., 1988). Lack of consistent control conveys a high risk to growers of high-value crops. Iodomethane (IM) tested as a soil fumigant has shown a broad spectrum of efficacy against pathogens, nematodes, and weeds similar to that obtained for $\mathrm{MBr}$ (Becker et al., 1998; Eayre et al., 2000; Hutchinson et al., 1999; Ohr et al., 1996; Schneider et al., 2005; Stanghellini et al., 2003; Zhang et al., 1997). Iodomethane was recently registered in 44 states (excluding California and Florida) of the United States (EPA, personal communication). Propargyl bromide ( $\mathrm{PBr}$ ), a compound patented by Dow Chemical in 1957, is an effective broad-spectrum soil fumigant (Ajwa et al., 2001; Hutchinson et al., 2004; U.S. Patent Office, 1957; Yates and Gan, 1997), but is a difficult material to safely manufacture and transport and is not currently registered for use.

Historically, fumigants have been most commonly applied by shank injection into the soil. In earlier trials of drip application of nematocides for bulb crops in fine-textured soils, nematode control efficacy varied relative to the control achieved with the industry standard shank-injected protocols (Westerdahl et al., 1993, 2003). Delivery of nematicidal materials to soil depths greater than $60 \mathrm{~cm}$ is critical, even in annual crops, to achieve acceptable nematode control and improve crop growth. In field tests, drip application of fumigants in sandy loam soils 
has provided good nematode control when used with both current commercially available compounds such as 1,3-D and Pic and those not yet on the market at the time of testing such as IM and $\mathrm{PBr}$ (Ajwa and Trout, 2004; Ajwa et al., 2002; Schneider et al., 2005). The improvements in application equipment and methods, increased knowledge and understanding of fumigant distribution, and the moderately coarse soil texture likely contributed to the improved efficacy and consistency of nematode control after drip fumigation in the later trials. Some materials move easily and quickly through the soil profile, whereas others do not. A material can be effective at the point of application, but the fumigant must be distributed throughout the target zone at concentrations sufficient to kill soil pests. Drip application offers advantages such as a closed application system that limits worker exposure to fumigants during the application process and the potential to use the water percolation to move materials more uniformly through the soil profile that might not be possible with shank injection (Ajwa and Trout, 2004; Ajwa et al., 2002; Gan et al., 1998; Schneider et al., 1995).

The fate and distribution of fumigants in the soil profile can be used indirectly to evaluate fumigation efficacy by monitoring fumigant concentrations in the soil vapor phase as a function of time throughout the soil profile (Ajwa et al., 2002). In-field pest control efficacy, however, is a more direct measure of fumigant performance and must be documented using either native pest and pathogen populations or by using a bioassay. By combining fumigant concentration monitoring with a bioassay test, a dose-response curve (soil pest control efficiency versus fumigant exposure) can be obtained and used to evaluate the effectiveness of fumigation methods and application rates. Fumigant exposure index $(\mathrm{C} \times \mathrm{T}$, where $\mathrm{C}$ is fumigant concentration in $\mathrm{mg} \cdot \mathrm{L}^{-1}$ and $\mathrm{T}$ is the time in h) was used to correlate with pest control (Gamliel et al., 1997; Gan et al., 1999).

It can be difficult to find nematodeinfested field research sites for crops such as strawberry and certified nurseries because most have traditionally been fumigated before each crop. Bags containing fungal spores, weed seeds, or nematode-infested soil can be used as a bioassay system when naturally infested fields are not available (Browne et al., 2003a; Fennimore et al., 2003; Zasada et al., 2003). If there is a need to avoid the potential for introducing a broad host range nematode such as Meloidogyne spp. Chitwood, the root-knot nematode, into a field, a nematode with a relatively narrow host range such as Tylenchulus semipenetrans Cobb, the citrus nematode, can be used for the bioassay. If there is not a concern, as was the case for the 2000 and 2001 trials in this study, the more economically important root-knot nematode can be used. The experimental details such as depth and placement of the bags were modified between trials to account for variation in crop and field and built on the knowledge acquired in the previous trials. The disadvantages of using the buried bag bioassay system are the potential for differential flow of experimental materials through the disturbed soil as compared with movement through normally cultivated soil as well as the possibility that the specific pest or pathogen chosen for the bioassay might respond differently to the experimental materials than other pests and pathogens of interest might respond.

The objective of the research reported here was to compare the efficacy of shank-injection and drip-application of potential chemical alternatives to $\mathrm{MBr}$ for nematode control and to evaluate different rates of both registered and unregistered materials under field conditions. Several field trials were conducted for 3 years in strawberry or perennial nursery fields in central California to evaluate alternatives and effective application methods for alternative fumigants to $\mathrm{MBr}$.

\section{Materials and Methods}

To gain information applicable to a relatively large scale, three field trials were conducted to test alternative fumigants to $\mathrm{MBr}$ at different locations in central California in 3 consecutive years (1999 to 2001). All trials involved bioassay bags and nematode survival count.
Bioassay bags. Moist soil from orchard or nursery fields containing high levels of citrus nematode (Tylenchulus semipenetrans Cobb) juveniles and eggs or soil containing rootknot nematode (Meloidogyne spp. Chitwood) juveniles and eggs cultured on tomatoes in the greenhouse was collected and mixed well using a concrete mixer. Hubco Sand Sample Bags $(9 \mathrm{~cm} \times 13 \mathrm{~cm})$ (Hutchinson Bag Corp., Hutchinson, KS) were soaked and rinsed to remove sizing. Moist bags were filled with the specified amount of infested soil and stored briefly at $7{ }^{\circ} \mathrm{C}$ until buried in the field. Nylon fishing line was attached to each bag and brightly colored flagging tape was attached to the fishing line at the soil surface to aid in locating the bags after fumigation. Bags were buried on the day preceding the application of treatments to allow time for the soil temperature and moisture in the bag to equilibrate with the field soil. Bags were buried at relatively shallow depths $(15$ to $30 \mathrm{~cm})$ for strawberry, a shallow-rooted crop, and deeper (30 to $150 \mathrm{~cm}$ ) for grapes, a deep-rooted crop.

1999 trial. A research site was identified at the Bay Area Research and Education Center, Santa Clara, CA. The soil, Campbell silty clay loam (fine-silty, mixed, superactive, nonacid, thermic Cumulic Humaquepts), was cultivated and beds $(76 \mathrm{~cm}$ wide, $132 \mathrm{~cm}$ center-to-center, $30 \mathrm{~cm}$ high) were formed following standard cultural practices. Plots were one bed wide and $15 \mathrm{~m}$ long. The experimental design was a randomized complete block with six blocks, one replication per block. Bioassay bags were filled with $50 \mathrm{cc}$ of moist soil containing citrus nematode, Tylenchulus semipenetrans, and buried at $30-\mathrm{cm}$ depth in the center and on the shoulder of each bed.

Treatments are listed in Table 1 and were applied in August. Shank-injected fumigants were applied with a bed fumigation rig that injected fumigants at a depth of 25 to $30 \mathrm{~cm}$ through two chisels spaced $35 \mathrm{~cm}$ apart and immediately covered the bed with standard polyethylene mulch. In plots treated with dripapplied fumigants, two thin-walled drip tapes (TIGER TAPETM, Valplastic, Ontario, CA); emitters spaced $22 \mathrm{~cm}$ apart, emitter flow of $0.55 \mathrm{~L} \cdot \mathrm{h}^{-1}$ at $60 \mathrm{kPa}$ ) were placed $10 \mathrm{~cm}$ from the center of each bed at the soil surface and

Table 1. Treatments applied to Expt. 1, Santa Clara, CA, 1999.

\begin{tabular}{|c|c|c|c|}
\hline $\begin{array}{l}\text { Treatment } \\
\text { number }\end{array}$ & Field treatment description & $\begin{array}{l}\text { Application } \\
\text { method }\end{array}$ & $\begin{array}{c}\text { Followed by } \\
\text { drip-applied } \\
\text { metam sodium }\end{array}$ \\
\hline 1 & Untreated control & None & No \\
\hline 4 & 1,3-dicholoropropene $\left(267 \mathrm{~kg} \cdot \mathrm{ha}^{-1}\right)+$ chloropicrin $\left(152 \mathrm{~kg} \cdot \mathrm{ha}^{-1}\right)$ (Telone C35, 325 L $\cdot \mathrm{ha}^{-1}$, Dow Agrosciences) & Shank & Yes \\
\hline 5 & 1,3-dicholoropropene $\left(266 \mathrm{~kg} \cdot \mathrm{ha}^{-1}\right)+$ chloropicrin $\left(146 \mathrm{~kg} \cdot \mathrm{ha}^{-1}\right)$ (InLine, $325 \mathrm{~L} \cdot \mathrm{ha}^{-1}$, Dow Agrosciences $)$ & Drip & No \\
\hline 6 & 1,3-dicholoropropene $\left(270 \mathrm{~kg} \cdot \mathrm{ha}^{-1}\right)+$ chloropicrin $\left(146 \mathrm{~kg} \cdot \mathrm{ha}^{-1}\right)$ (InLine, $325 \mathrm{~L} \cdot \mathrm{ha}^{-1}$, Dow Agrosciences) & Drip & Yes \\
\hline 9 & Chloropicrin (224 L·ha ${ }^{-1}$, Niklor) & Shank & No \\
\hline 10 & Chloropicrin (224 L $\cdot \mathrm{ha}^{-1}$, Niklor) & Shank & Yes \\
\hline 11 & Chloropicrin (224 L·ha ${ }^{-1}$, Niklor) & Drip & No \\
\hline 12 & Chloropicrin (224 L $\cdot \mathrm{ha}^{-1}$, Niklor) & Drip & Yes \\
\hline 13 & None & None & Yes \\
\hline
\end{tabular}

${ }^{2}$ Metam sodium (Vapam HL, AmVac, $420 \mathrm{~L} \cdot \mathrm{ha}^{-1}$ of $42 \%$ a.i.) drip-applied in $25 \mathrm{~mm}$ water.

Tri-Cal Inc., Hollister, CA; Dow Agrosciences, Indianapolis, IN; Niklor, Mojave, CA. 
the entire bed was covered with standard polyethylene mulch. Drip fumigants were applied as described by Ajwa et al. (2002) in $35 \mathrm{~mm}\left(35 \mathrm{~L} \cdot \mathrm{m}^{-2}\right)$ water. Metam sodium treatments were applied in $25 \mathrm{~mm}\left(25 \mathrm{~L} \cdot \mathrm{m}^{-2}\right)$ water $5 \mathrm{~d}$ after the other treatments.

Bags were recovered 2 weeks after the metam sodium treatments were applied. Soil was removed from the bags and placed on Baermann funnels for $4 \mathrm{~d}$ to recover live nematodes (Flegg and Hooper, 1970). Nematodes were identified and counted under the microscope. Nematode counts were transformed using $\ln (x+1)$ to stabilize the variance (Noe, 1985). The transformed counts were analyzed using analysis of variance and means separated using the Waller-Duncan K-ratio $t$ test (SAS Institute Inc., 1985).

2000 trial. A Hanford sandy loam soil (coarse-loamy, mixed, superactive, nonacid, thermic Typic Xerorthents), previously fumigated with $\mathrm{MBr} / \mathrm{Pic}$, at the San Joaquin Valley Agricultural Science Center, Parlier, CA, was tilled and prepared for planting. Shank fumigated plots were $3.4 \mathrm{~m}$ wide and drip-fumigated plots were $1.5 \mathrm{~m}$ wide. All plots were $30.5 \mathrm{~m}$ long. The experimental design was a randomized complete block with four blocks, one replicate per block. Bioassay bags were filled with $50 \mathrm{cc}$ of moist soil containing root-knot nematode, Meloidogyne spp., juveniles and eggs and buried at 30-, 90-, and $150-\mathrm{cm}$ depths in the middle of each plot.

Treatments are listed in Table 2 and were applied in May. Shank-injected fumigants were applied by a commercial applicator using a noble plow that injected fumigants at a depth of 25 to $30 \mathrm{~cm}$ and immediately tarped the plot with a low-density polyethylene (LDPE) tarp. In plots treated with dripapplied fumigants, a single drip tape (emitters spaced $30 \mathrm{~cm}$ apart and emitter flow rate of $2 \mathrm{~L} \cdot \mathrm{h}^{-1}$ ) was placed in the center of each plot and the entire plot was tarped with lowdensity polyethylene mulch. Drip fumigants were applied as described by Ajwa et al. (2002) in $75 \mathrm{~mm}\left(75 \mathrm{~L} \cdot \mathrm{m}^{-2}\right)$ water.

Bags were recovered 2 weeks after treatment. Soil was removed from the bags and Hooper, 1970). The incubation time was lengthened from 4 to $7 \mathrm{~d}$ to allow for greater recovery of live nematodes. Nematodes were counted and data analyzed as previously described. placed on Baermann funnels for $7 \mathrm{~d}$ (Flegg and

2001 trial. The research site was located at the Monterey Bay Academy near Watsonville, CA. The soil, Elder sandy loam (coarseloamy, mixed, superactive, thermic Cumulic Haploxerolls), was cultivated and beds were formed following standard cultural practices for strawberry production. The field designs were the same as in the 1999 field trial. Bioassay bags were filled with $100 \mathrm{cc}$ soil containing root-knot nematode juveniles and eggs and buried at $15-$ and $30-\mathrm{cm}$ depths in the center of each bed.

Treatments included an untreated control and three rates of drip-applied $\mathrm{PBr}$ (Albemarle, Inc., Baton Rouge, LA): 67, 134, and $202 \mathrm{~kg} \cdot \mathrm{ha}^{-1}$. Fumigants were applied through two drip tapes (Netafim Streamline ${ }^{\top M}$, Netafim, Fresno, CA) with emitters spaced $30 \mathrm{~cm}$ apart and emitter flow rate of $1.5 \mathrm{~L} \cdot \mathrm{h}^{-1}$ at $69 \mathrm{kPa}$ ) placed $10 \mathrm{~cm}$ from either side of the center of each plot under standard LDPE mulch. Fumigants were applied in October as described by Ajwa et al. (2002) in $45 \mathrm{~mm}$ water. Bags were recovered 2 weeks after treatment. Soil was removed from the bags and processed as previously described. Nematodes were counted and data analyzed as previously described.

Fumigant concentration in the soil profile. To evaluate the efficacy of various treatments, total fumigant concentrations in the soil air space at the depths where nematode bags were buried in the soil bed were measured up to $72 \mathrm{~h}$ in the 1999 and 2000 trials and $96 \mathrm{~h}$ in the 2001 trial. Fumigant sampling and analysis were conducted following procedures described by Ajwa et al. (2002). In brief, stainless steel soil-air sampling probes (1.0 $\mathrm{mm}$ i.d.) were placed at various depths $(5,15$, $30,45,60$, and $90 \mathrm{~cm}$ ). Only the data at the depths where nematode bags were buried are presented in this article. Soil-air samples were taken by extracting $50 \mathrm{~mL}$ of soil air through sorbents (XAD- $4^{\circledR}$ resin cartridges for 1,3-D and Pic or ORBO-32 charcoal for IM and $\mathrm{PBr}$ ) (Sigma-Aldrich, Milwaukee, WI) using a 50 -mL airtight syringe. The trapped fumigants were extracted from the cartridges with hexane and analyzed using an Agilent ${ }^{\circledR}$ (Wilmington, DE) 6890 series gas chromatograph system equipped with an Agilent $5973 \mathrm{~N}$ mass selective detector and a Zebron ZB-624 column (Phenomenex, Torrance, CA) $(30 \mathrm{~m} \times$ $0.25 \mathrm{~mm}$ i.d. $\times 1.4 \mu \mathrm{m}$ film thickness $)$. Soil

Table 2. Treatments applied to Expt. 2, Parlier, CA, 2000.

\begin{tabular}{|c|c|c|}
\hline $\begin{array}{l}\text { Treatment } \\
\text { number }\end{array}$ & Treatment description & $\begin{array}{l}\text { Application } \\
\text { method }\end{array}$ \\
\hline$\overline{1}$ & Untreated control & None \\
\hline 2 & $\begin{array}{l}\text { Methyl bromide: chloropicrin } 66: 33 \\
\left(448 \mathrm{~kg} \cdot \mathrm{ha}^{-1} \text {, Tri-Cal, industry standard) }\right.\end{array}$ & Shank \\
\hline 3 & $\begin{array}{l}\text { Iodomethane }\left(224 \mathrm{~kg} \cdot \mathrm{ha}^{-1}\right)+\text { chloropicrin } \\
\left(224 \mathrm{~kg} \cdot \mathrm{ha}^{-1}, \text { Midas }^{\mathrm{TM}} \text { 50:50, Arysta }\right)\end{array}$ & Shank \\
\hline 4 & $\begin{array}{l}\text { Iodomethane }\left(224 \mathrm{~kg} \cdot \mathrm{ha}^{-1}\right)+\text { chloropicrin } \\
\left(224 \mathrm{~kg} \cdot \mathrm{ha}^{-1}, \text { Midas }^{\mathrm{TM}} \text { 50:50, Arysta }\right)\end{array}$ & Drip \\
\hline 5 & $\begin{array}{l}\text { Iodomethane }\left(112 \mathrm{~kg} \cdot \mathrm{ha}^{-1}\right)+\text { chloropicrin } \\
\left(112 \mathrm{~kg} \cdot \mathrm{ha}^{-1}, \text { Midas }^{\mathrm{TM}} \text { 50:50, Arysta }\right)\end{array}$ & Drip \\
\hline 6 & Propargyl bromide (112 kg.ha ${ }^{-1}$, Albemarle) & Drip \\
\hline 7 & Propargyl bromide (224 kg $\cdot \mathrm{ha}^{-1}$, Albemarle) & Drip \\
\hline 8 & 1,3-dichloropropene (437 kg.ha ${ }^{-1}$, Telone EC, Dow Agrosciences) & Drip \\
\hline
\end{tabular}

gaseous concentrations, measured at the same depth where nematode bags were placed [30$\mathrm{cm}$ depth in Campbell silty clay loam (1999 trial); 30- and 90-cm depths in Hanford sandy loam soil (2000 trial); and 15- and 30-cm depth in Elder sandy loam (2001 trial)], were used to estimate the dosage for each depth from concentration $\left(\mathrm{mg} \cdot \mathrm{L}^{-1}\right)$ versus time $(\mathrm{h})$ graphs using SigmaPlot Version 7.0 software program (SPSS, Inc., Chicago). The dosage $\left(\sum\right.$ concentration $\times$ time $)$ was estimated from the area under the curve of fumigant concentration $\left(\mathrm{mg} \cdot \mathrm{L}^{-1}\right)$ plotted over time $(\mathrm{h})$. Integration of fumigant concentration $\times$ time provides the dosage values in $\mathrm{mg} \cdot \mathrm{L}^{-1} \cdot \mathrm{h}$ to which the nematodes were exposed. This approach has been validated for nematode fumigant exposure durations of up to 7 d (McKenry and Thomason, 1974).

\section{Results}

In the 1999 trial, all treatments significantly reduced the number of mobile nematodes in bags buried in the center of the bed compared with the untreated control (Table 3). Vapam alone (metam sodium; Trt 13) provided no control at the shoulders of the beds. Drip-applied Pic (Trt 11) did not control the nematodes at the shoulder of the beds, and the addition of a metam sodium treatment after the Pic (Trt 12) did not improve control. In the 2000 trial, all treatments provided control similar to $\mathrm{MBr} / \mathrm{Pic}$ at the 30-cm depth (Table 4). At the 90-cm depth, all treatments had similar efficacy to $\mathrm{MBr} / \mathrm{Pic}$ except drip-applied 1,3-D (Trt 8). At the $150-\mathrm{cm}$ depth, both $\mathrm{PBr}$ treatments (Trts 6 and 7) and the 1,3-D treatment (Trt 8) were statistically similar to the untreated control. The IM + Pic treatments (Trts 3, 4, and 5) gave control similar to $\mathrm{MBr} / \mathrm{Pic}$ at all three soil depths. In the 2001 trial, all treatments with $\mathrm{PBr}$ provided sufficient control for Meloidogyne spp. and there was no difference in level of nematode control achieved at either the 15 - or 30-cm depths as a function of the increasing rates of $\mathrm{PBr}$ (Table 5).

The distribution patterns of 1,3-D (cisplus trans-isomers) in half of the bed profile of the Campbell silty clay loam soil (1999 trial) $36 \mathrm{~h}$ after applying InLine (Dow Agrosciences, Indianapolis, IN) (drip fumigation) and Telone C35 (Dow Agrosciences, Indianapolis, IN) (shank injection) at $325 \mathrm{~kg} \cdot \mathrm{ha}^{-1}$ are presented in Figure 1. These results are averages of duplicate samples. In general, maximum 1,3-D concentrations at this location were measured 24 to $36 \mathrm{~h}$ after fumigation. The Pic distribution patterns (data not shown) were similar to the 1,3-D patterns and Pic concentrations were $30 \%$ to $40 \%$ of $1,3-D$ concentrations during the initial $36 \mathrm{~h}$.

The dosage values were calculated based on fumigant concentrations monitored in soil gaseous phase over a period of 72 or $96 \mathrm{~h}$ at the depths at which nematode bags were buried before fumigation and recovered $\approx 2$ to 3 weeks later (Fig. 2). Thus, the actual dosage time the nematode bags were exposed to was longer than the measurement time, but 
Table 3. 1999 experiment: fumigant dosage and number of mobile Tylenchulus semipenetrans, citrus nematode, per 50 cc soil recovered from sample bags buried $30 \mathrm{~cm}$ deep in a Campbell silty clay loam soil in Santa Clara, CA.

\begin{tabular}{|c|c|c|c|c|c|}
\hline \multirow[b]{2}{*}{$\begin{array}{l}\text { Treatment } \\
\text { number }\end{array}$} & \multirow[b]{2}{*}{ Treatment description } & \multicolumn{2}{|c|}{ Bed center } & \multicolumn{2}{|c|}{ Bed Shoulder } \\
\hline & & $\begin{array}{c}\text { Nematodes/ } \\
\text { bag }^{z}\end{array}$ & $\begin{array}{l}\text { Dosage }^{y} \\
\text { mg } \cdot \mathrm{L}^{-1} \cdot h\end{array}$ & $\begin{array}{c}\text { Nematodes/ } \\
\text { bag }^{z}\end{array}$ & $\begin{array}{l}\text { Dosage }^{y} \\
\mathrm{mg} \cdot \mathrm{L}^{-1} \cdot \mathrm{h}\end{array}$ \\
\hline 1 & Untreated & $75.8 \mathrm{a}$ & N/A & $124.8 \mathrm{a}$ & N/A \\
\hline 4 & Telone C35 (325 L $\left.\cdot \mathrm{ha}^{-1}\right)$, shank-injected + Vapam ( $420 \mathrm{~L} \cdot \mathrm{ha}^{-1}$ in $25 \mathrm{~mm}$ water $)$ & $0.2 \mathrm{bc}$ & $54+24$ & $0.2 \mathrm{c}$ & $78+40$ \\
\hline 5 & InLine $\left(325 \mathrm{~L} \cdot \mathrm{ha}^{-1}\right)$, drip & $0.0 \mathrm{c}$ & $73+14$ & $0.0 \mathrm{c}$ & $29+9$ \\
\hline 6 & InLine $\left(325 \mathrm{~L} \cdot \mathrm{ha}^{-1}\right)$ drip + Vapam ( $420 \mathrm{~L} \cdot \mathrm{ha}^{-1}$ in $25 \mathrm{~mm}$ water $)$ & $1.6 \mathrm{~b}$ & $73+14$ & $0.9 \mathrm{c}$ & $29+9$ \\
\hline 9 & Chloropicrin $\left(224 \mathrm{~L} \cdot \mathrm{ha}^{-1}\right)$ shank- injected & $0.0 \mathrm{c}$ & $0+10$ & $0.9 \mathrm{c}$ & $0+18$ \\
\hline 10 & Chloropicrin $\left(224 \mathrm{~L} \cdot \mathrm{ha}^{-1}\right)$, shank + Vapam $\left(420 \mathrm{~L} \cdot \mathrm{ha}^{-1}\right.$ in $25 \mathrm{~mm}$ water $)$ & $0.3 \mathrm{bc}$ & $0+10$ & $1.3 \mathrm{c}$ & $0+18$ \\
\hline 11 & Chloropicrin $\left(224 \mathrm{~L} \cdot \mathrm{ha}^{-1}\right)$, drip & $1.0 \mathrm{bc}$ & $0+21$ & $9.9 \mathrm{~b}$ & $0+8$ \\
\hline 12 & Chloropicrin $\left(224 \mathrm{~L} \cdot \mathrm{ha}^{-1}\right)$, drip + Vapam $\left(420 \mathrm{~L} \cdot \mathrm{ha}^{-1}\right.$ in $25 \mathrm{~mm}$ water $)$ & $0.0 \mathrm{c}$ & $0+21$ & $20.3 \mathrm{~b}$ & $0+8$ \\
\hline 13 & Vapam (420 L $\cdot \mathrm{ha}^{-1}$ in $25 \mathrm{~mm}$ water) & $0.0 \mathrm{c}$ & N/A & $284.2 \mathrm{a}$ & N/A \\
\hline
\end{tabular}

${ }^{\mathrm{z}}$ Mean of six replications. Statistical analyses conducted on log-transformed $[\ln (\mathrm{n}+1)]$ data. Data presented are the antilogs [e $\left.\mathrm{e}^{(\mathrm{means})}-1\right]$. Means for each sample location followed by the same letter in the same column are not significantly different at the $P=0.05$ level.

${ }^{\mathrm{y}}$ The 1,3-D and chloropicrin dosage values at $30-\mathrm{cm}$ soil depths were estimated from concentration versus time curves over $72 \mathrm{~h}$. The first value is the 1,3-D (cis- and trans-isomers) dosage and the second value is the chloropicrin dosage.

$\mathrm{N} / \mathrm{A}=$ not available.

Table 4. 2000 experiment: fumigant dosage and number of mobile Meloidogyne spp., root-knot nematode, per 50 cc soil recovered from sample bags buried in a Hanford sandy loam soil in Parlier, CA.

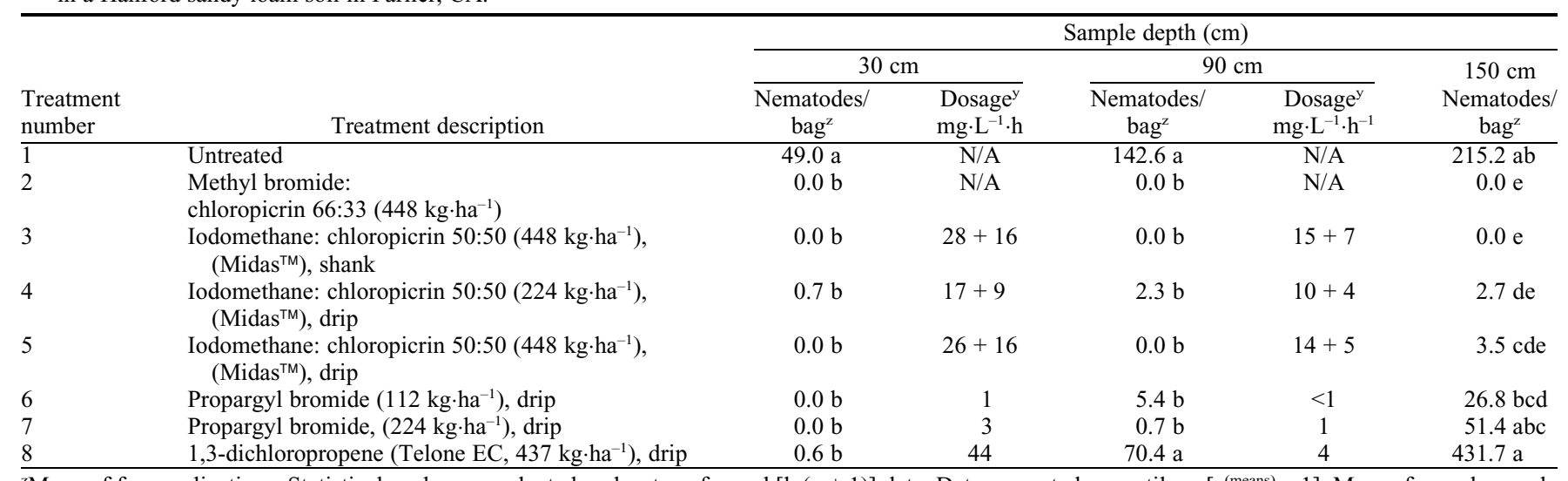

${ }^{\mathrm{z}}$ Mean of four replications. Statistical analyses conducted on log-transformed $[\ln (\mathrm{n}+1)]$ data. Data presented are antilogs [e $\left.{ }^{(\text {means })}-1\right]$. Means for each sample depth followed by the same letter are not significantly different at the $P=0.05$ level.

${ }^{\mathrm{y}}$ Dosage values were estimated from concentration versus time curves over $72 \mathrm{~h}$. Fumigant concentrations were not measured at the 150 -cm depth. Midas ${ }^{\mathrm{TM}}$ dosage is presented for iodomethane (first value) and chloropicrin (second value).

$\mathrm{N} / \mathrm{A}=$ not available.

Table 5. 2001 experiment: number of mobile Meloidogyne spp., root-knot nematode, per $100 \mathrm{cc}$ soil recovered from sample bags buried in an Elder sandy loam soil near Watsonville, CA.

\begin{tabular}{lccc}
\hline & & \multicolumn{2}{c}{ Sample depth $^{\mathrm{z}}$} \\
\cline { 3 - 4 } Treatment no. & Treatment description & $15 \mathrm{~cm}$ & $30 \mathrm{~cm}$ \\
& Nematodes $/ \mathrm{bag}^{y}$ & Nematodes $/ \mathrm{bag}^{\mathrm{y}}$ \\
\hline 1 & Propargyl bromide $\left(67 \mathrm{~kg} \cdot \mathrm{ha}^{-1}\right)$, drip & $28.5 \mathrm{a}$ & $31.7 \mathrm{a}$ \\
2 & Propargyl bromide $\left(134 \mathrm{~kg} \cdot \mathrm{ha}^{-1}\right)$, drip & $0.0 \mathrm{~b}$ & $0.5 \mathrm{~b}$ \\
3 & Propargyl bromide $\left(202 \mathrm{~kg} \cdot \mathrm{ha}{ }^{-1}\right)$, drip & $0.0 \mathrm{~b}$ & $0.0 \mathrm{~b}$ \\
4 &
\end{tabular}

${ }^{\mathrm{z}}$ Fumigant concentration was measured in the middle of the soil bed. The calculated propargyl bromide dosages over $96 \mathrm{~h}$ for the lowest application rate $\left(67 \mathrm{~kg} \cdot \mathrm{ha}^{-1}\right)$ were 4.7 and $2.8 \mathrm{mg} \cdot \mathrm{L}^{-1} \cdot \mathrm{h}$ air for 15 - and 30 -cm depth, respectively.

${ }^{y}$ Mean of four replications. Statistical analyses conducted on $\log$-transformed $[\ln (n+1)]$ data. Data presented are the antilogs $\left[\mathrm{e}^{(\text {means) }}-1\right]$. Means for each sample depth followed by the same letter are not significantly different at the $P=0.05$ level.

our monitoring of fumigant concentrations showed that by 72 or $96 \mathrm{~h}$ after fumigation, fumigant concentrations became so low that exposure to fumigants were negligible after $72 \mathrm{~h}$ (Fig. 2). In the 1999 trial, dosage of 1,3$\mathrm{D}$ was greater in the bed center when 1,3-D + Pic was drip-applied compared with shank- injected (Trts 3, 4, 5, and 6), but Pic dosage was greater when shank-injected (Table 3). At the bed shoulder, 1,3-D and Pic were higher when shank-injected as Telone C35 (Trts 3 and 4) compared with drip-applied as InLine (Trts 5 and 6). When Pic was applied alone, higher dosages were found in the bed center in drip-applied treatments (Trts 11 and 12) and at bed shoulders in shank-injected treatments (Trts 9 and 10). In the 2000 trial, there was no difference based on application method in the resulting dosages of IM and Pic at 30- or 90-cm soil depths (Table 4). Dosage of IM and Pic at $90 \mathrm{~cm}$ was approximately half of the dosage at $30 \mathrm{~cm}$ (Trts 3, 4, and 5), except for Pic in the drip-applied $448 \mathrm{~kg} \cdot \mathrm{ha}^{-1}$ rate of Midas ${ }^{\mathrm{TM}}$ (Arysta Lifescience, Cary, NC) (Trt 5) where the 90-cm dosage was 30\% of the $30-\mathrm{cm}$ dosage. In the 2001 trial, the $\mathrm{PBr}$ dosage at $30 \mathrm{~cm}$ was $60 \%$ of the dosage at $15 \mathrm{~cm}$ (Table 5).

To evaluate the fumigants' efficacy in controlling nematodes in these field trials, the dose-response curves were plotted (Fig. 3). For $\mathrm{PBr}$, a dosage of $0.5 \mathrm{mg} \cdot \mathrm{L}^{-1} \cdot \mathrm{h}$ provided $96 \%$ nematode control and when dosage increased to $1 \mathrm{mg} \cdot \mathrm{L}^{-1}$ and above (up to 5 $\left.\mathrm{mg} \cdot \mathrm{L}^{-1} \cdot \mathrm{h}\right), 99 \%$ to $100 \%$ nematode control was obtained. For application of 1,3-D combined with Pic formulated as Telone C35 (35\% Pic) and InLine (33\% Pic), at dosage values 


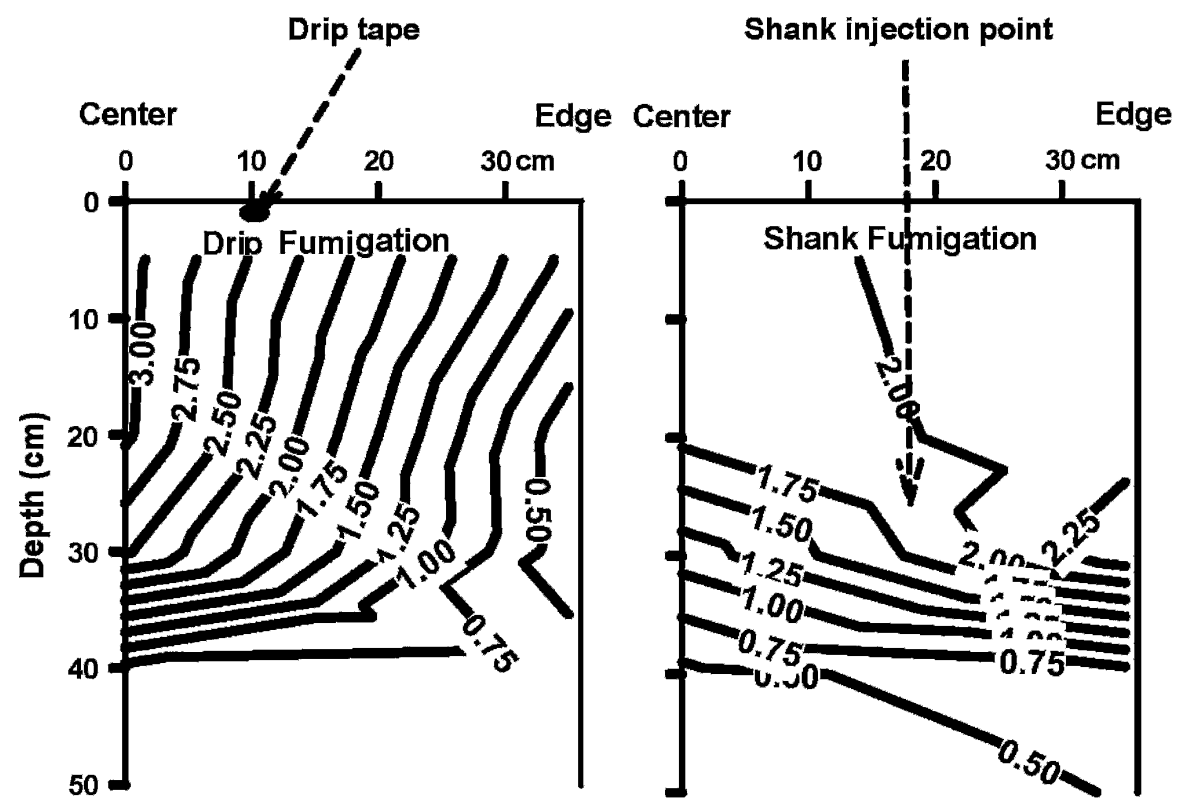

Fig. 1. 1,3-dichloropropene concentration (mg. $\mathrm{L}^{-1}$ air) in the soil gaseous phase of a Campbell silty loam soil at the center and edge of the plant bed $36 \mathrm{~h}$ after drip fumigation with InLine (left) and shank injection with Telone C35 (right) at $325 \mathrm{~L} \cdot \mathrm{ha}^{-1}$.

of 17 up to $118 \mathrm{mg} \cdot \mathrm{L}^{-1} \cdot \mathrm{h}(74 \%$ as $1,3-\mathrm{D}$ and $26 \%$ as Pic), $99 \%$ to $100 \%$ nematode control was obtained. When Telone EC (containing 1,3-D only) was drip-applied, a dosage of 4 $\mathrm{mg} \cdot \mathrm{L}^{-1} \cdot \mathrm{h}$ gave only $51 \%$ nematode control and a dosage of $44 \mathrm{mg} \cdot \mathrm{L}^{-1}$ provided $100 \%$ control. For Pic applied alone, a dosage of 10 $\mathrm{mg} \cdot \mathrm{L}^{-1} \cdot \mathrm{h}$ provided $99.6 \%$ to $100 \%$ nematode control, but a dosage of $8 \mathrm{mg} \cdot \mathrm{L}^{-1} \cdot \mathrm{h}$ provided only $84 \%$ to $92 \%$ control. For applications of IM and Pic at a 50:50 mass ratio, 98\% and $100 \%$ of nematode control were obtained at a dosage of 14 and $19 \mathrm{mg} \cdot \mathrm{L}^{-1} \cdot \mathrm{h}$, respectively, in which the dosages were comprised of $77 \%$ IM and 33\% Pic.

\section{Discussion}

The agricultural research and production communities relied on shank-injected $\mathrm{MBr}$ to reduce the risk of crop loss resulting from soilborne pests and pathogens for more than 40 years before its phase-out. The broad spectrum of activity of $\mathrm{MBr}$ and its consistent efficacy over a wide range of soil conditions have made the search for alternatives challenging. New materials have been evaluated and alternative application technologies explored (e.g., Gerik, 2005; McKenry et al., 2003; Rodriguez-Kabana, 2005; RodriguezKabana et al., 2005; Westerdahl et al., 2003). Some materials have shown good efficacy, but all alternatives are less volatile than $\mathrm{MBr}$ and may require alternative approaches to deliver the material to the target pests and pathogens under specific soil conditions such as fine soil textures, wet soils, and cool soils. Results presented here demonstrated that drip-irrigation technologies to deliver emulsified formulations of fumigants is promising for the control of plant parasitic nematodes. This technology has been successfully adopted by over $50 \%$ of California strawberry growers for fumigating their bedded, mulched, and drip-irrigated fields.

The 1999 trial and the 2001 trial represent conditions likely to be encountered in a bedfumigated, shallow-rooted annual crop such as strawberry. Fumigant distribution may be affected by application methods (Fig. 1). Different distribution patterns of 1,3-D in the soil air phase was observed in drip versus shank applications at $36 \mathrm{~h}$ after fumigation between bed center and edge locations along soil depth. Shank injection generally resulted the soil gas phase across the bed (horizontally) than the drip application as indicated by the small concentration gradient at $20-\mathrm{cm}$ depth (from 1.75 at the bed center to 2.25 $\mathrm{mg} \cdot \mathrm{L}^{-1}$ near the bed edge). In contrast, the drip-applied fumigant showed much larger concentration gradient (from $3.00 \mathrm{mg} \cdot \mathrm{L}^{-1}$ near the bed center to $0.50 \mathrm{mg} \cdot \mathrm{L}^{-1}$ near the edge) at the $20-\mathrm{cm}$ depth. The contrasting results in fumigant concentration in the soil gas phase (i.e., highest concentration near bed center for drip and near the edge for shank) was the result of the water application from the drip application and subsequent distribution and fumigant partitioning between the gas and liquid phases. Higher fumigant concentrations in the gas phase correspond to higher concentrations in the liquid phase according to Henry's Law constant. Thus, the distribution pattern of fumigant concentration in the soil gas phase may also reflect fumigant concentration in the liquid phase.

Although the drip tapes placed close to the center of the bed (20 cm apart) resulted in large concentration differences across the bed, drip application of $\mathrm{PBr}, 1,3-\mathrm{D}$, Pic, and combinations of 1,3-D and Pic provided nematode control in the center of formed beds similar to shank-injection of the same in more uniform distribution of fumigants in materials and comparable to the industry standard $\mathrm{MBr} / \mathrm{Pic}$. Drip-applied metam sodium was also effective in killing nematodes in the center of the plant beds. Similar results have been documented for fungal pathogens and weeds (Browne et al., 2003b; Fennimore et al., 2003; Stanghellini et al., 2003). The lack of nematode control in the shoulders of beds treated with Vapam (Amvac Chemical Corp., Newport Beach, CA) (applied in $25 \mathrm{~mm}$ water) may suggest that the material did not move laterally to the edge of the beds at a sufficient concentration to be effective. The drip tapes were located $\approx 26 \mathrm{~cm}$ from the shoulder of the bed. Our results are in agreement with data reported by Ajwa and Trout (2004) indicating a minimum of $35 \mathrm{~mm}$ of water is needed to deliver the fumigant to the shoulders of the beds.

The 2000 trial represents conditions similar to those found in a broadcast-fumigated certified nursery for perennial crops such as vines, trees, or roses. For certified nursery crops, not only must the aboveground parts of the plant be healthy and vigorous, but the roots must be free of detectable plant parasitic nematodes (CDFA, 2002). Effective nematode control to a depth of $150 \mathrm{~cm}$ is often used as a criterion for evaluating new materials as potential alternatives to $\mathrm{MBr}$ use for certified nurseries. Our results demonstrate that IM + Pic applied either through shank-injection or by drip-fumigation was comparable to $\mathrm{MBr} / \mathrm{Pic}$ at achieving this goal. The loss of efficacy at deeper soil depths by $1,3-\mathrm{D}$ and $\mathrm{PBr}$ is likely a result of the inability to deliver the material to these depths with the application protocols in this trial. The small 1,3-D concentrations (dosage of $4 \mathrm{mg} \cdot \mathrm{L}^{-1} \cdot \mathrm{h}$ air) measured at $90-\mathrm{cm}$ depth in the 2000 trial were not sufficient to control the nematodes, most probably as a result of inadequate water penetration to this depth. The soil at this location contained hard layers between $30-$ and $60-\mathrm{cm}$ depths, which required deep ripping and intensive soil preparation. The soil was relatively dry at the time of application, and increasing the amount of water would likely increase the depth of distribution and resulting nematode control. However, the hard layer in this particular treatment may have remained intact and prevented water penetration to deeper depths. In other field trials in which both 1,3-D and $\mathrm{PBr}$ were applied in $75 \mathrm{~mm}$ water to a soil with higher soil moisture, good nematode control was demonstrated to a depth of $150 \mathrm{~cm}$ (Schneider et al., 2001).

The effective dosage values for nematode control with 1,3-D observed in these field trials are comparable to values found in the literature. McKenry and Thomason (1974) measured lethal dosage value of cis-1,3-D for Meloidogyne javanica was 1.2 to 1.3 $\mathrm{mg} \cdot \mathrm{L}^{-1} \cdot \mathrm{d}$ (equivalent to $30 \mathrm{mg} \cdot \mathrm{L}^{-1} \cdot \mathrm{h}$ ) at temperatures from 15 to $25^{\circ} \mathrm{C}$. Our observed effective control values were $12 \mathrm{mg} \cdot \mathrm{L}^{-1} \cdot \mathrm{h}$ for greater than $99 \%$ control. The lower value in our study may be the result of the synergistic effect of Pic that was not included in dosage calculations (Munnecke and Van Gundy, 

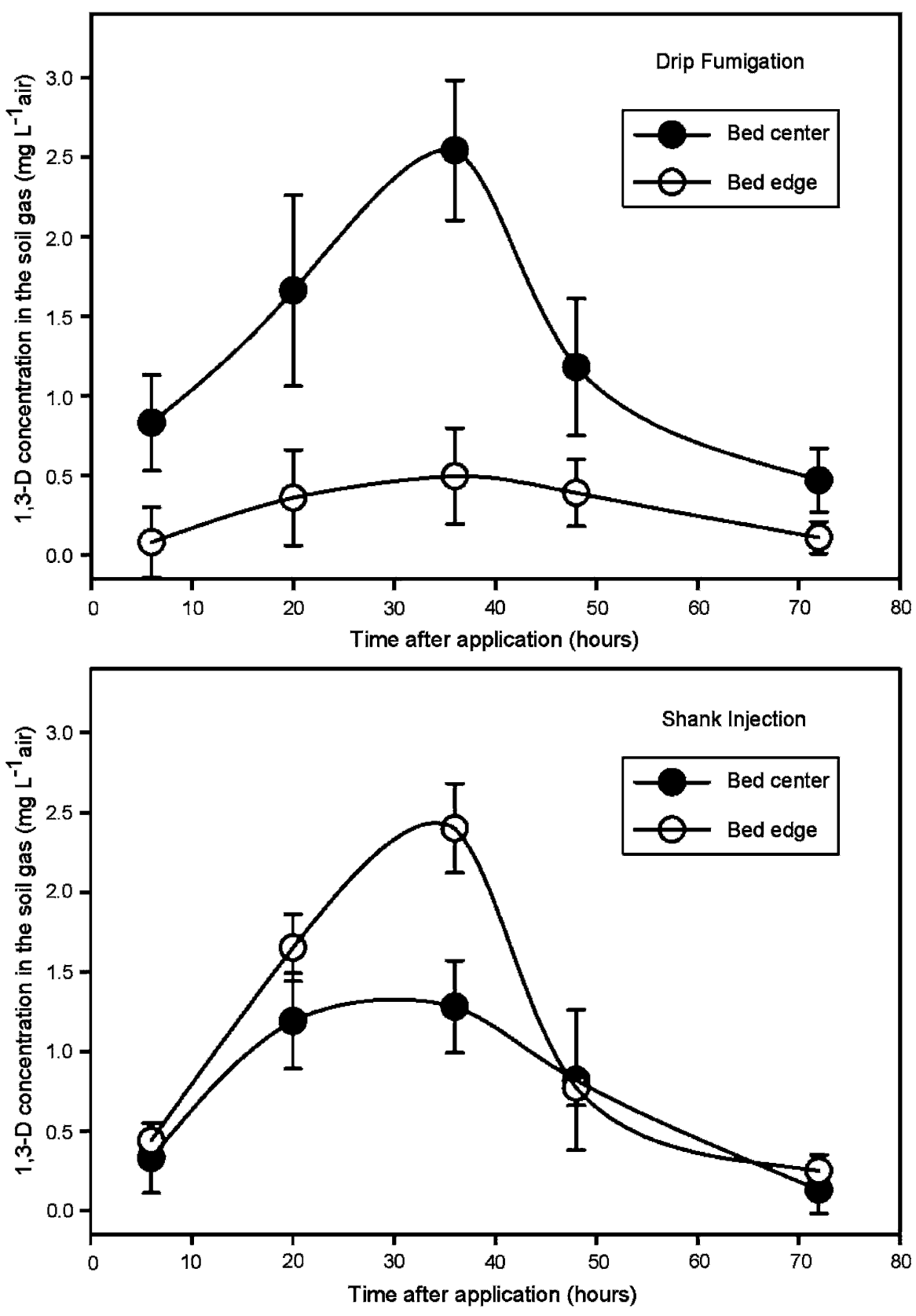

Fig. 2. 1,3-dichloropropene (1,3-D) concentration $\left(\mathrm{mg} \cdot \mathrm{L}^{-1}\right.$ air) in the soil gaseous phase of a Campbell silty loam soil after drip fumigation with InLine (top) and shank injection with Telone C35 (bottom) at $325 \mathrm{~L} \cdot \mathrm{ha}^{-1}$ at $30-\mathrm{cm}$ depth.

1979). As the dosage increased to 29 or above, consistent control was obtained $(99 \%$ to $100 \%$ ) (Fig. 3). Cis-1,3-D is reported to be more effective in the control of nematodes than trans-1,3-D and our dosage values did not separate the two isomers. Trans-1,3-D was reported $\approx 60 \%$ and $90 \%$ as toxic as the cis-1,3-D in the soil-water phase and vapor phase, respectively (McKenry and Thomason, 1974). For complete kill of root-knot nematode juveniles in soils, the lethal dosage values in the water phase of $c i s-1,3-\mathrm{D}$ and trans-1,3-D were $\approx 30$ and $40 \mathrm{mg} \cdot \mathrm{L}^{-1} \cdot \mathrm{d}$, respectively (McKenry and Thomason, 1976).

Information on the lethal dosages for soil pests for IM, Pic, and $\mathrm{PBr}$ is limited. In the trials presented here, $\mathrm{PBr}$ appeared to be the

variety of insects (wheat aphid, vine mealybug, red scale, grain moths, and mites) were killed within $2 \mathrm{~h}$ after exposure to $96 \mathrm{mg} \cdot \mathrm{L}^{-1}$ (a dosage of $184 \mathrm{mg} \cdot \mathrm{L}^{-1} \cdot \mathrm{h}$ ) of IM. Our observed effective dosage values for controlling nematodes with IM are much lower $(\approx 14$ $\mathrm{mg} \cdot \mathrm{L}^{-1} \cdot \mathrm{h}$ or below). Lethal dosage of fumigants for soil pests is also a function of temperature (McKenry and Thomason, 1974; Xue et al., 2000). The dosage required for nem-

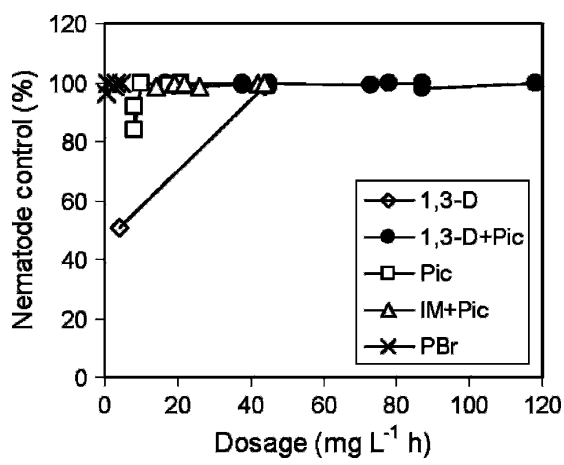

Fig. 3. Control for nematodes (Tylenchulus semipenetrans and Meloidogyne spp.) and the dosage exposure (within 72 or $96 \mathrm{~h}$ ) to fumigants from three field trials. Dosage values for 1,3-D were the sum of cis-1,3-D and trans-1,3-D, and were from combined application with chloropicrin (Pic) as Telone C35 or InLine. Dosage values for iodomethane were from application with Pic at a ratio of 50:50.

atode mortality at $30{ }^{\circ} \mathrm{C}$ was less than $50 \%$ of that needed at $20^{\circ} \mathrm{C}$ for both $\mathrm{MBr}$ and 1,3D (Xue et al., 2000). Generally speaking, the dosage values obtained from our field trials supported the fact that efficient nematode control can be achieved with the fumigation methods and application rates evaluated.

In conclusion, shank-injected and dripapplied 1,3-D + Pic mixtures and IM + Pic mixtures demonstrated good efficacy of nematode control over the range of soil types, soil depths, and locations within the plant bed evaluated in our studies. Further refinement of application protocols should lead to the ability to also deliver an effective concentration of $\mathrm{PBr}$, Telone EC, and Pic EC throughout the soil profile and across the plant bed. The key factors need to be determined to successfully deliver the fumigants to the targeted pests and pathogens, both laterally and vertically. Methyl bromide moves easily throughout the soil profile because of its high volatility. Successful drip application of less volatile materials, especially to deeper soil depths as is necessary for certified nursery production systems, requires a greater understanding of the interplay between the physical and chemical properties of the soil, the chemical characteristics of the fumigant, and basic biology of the pests and pathogens. More research and experience with drip fumigation or other new technologies over a diverse range of cropping systems, pest and pathogen populations, and soil conditions are continuously needed for successful transition from $\mathrm{MBr}$ to alternative fumigants.

\section{Literature Cited}


Ajwa, H.A. and T. Trout. 2004. Drip application of alternative fumigants to methyl bromide for strawberry production. HortScience 39:1707-1715.

Ajwa, H.A., T. Trout, J. Mueller, S. Wilhelm, S.D. Nelson, R. Soppe, and D. Shatley. 2002. Application of alternative fumigants through drip irrigation systems. Phytopathology 92:1349-1355.

Becker, J.O., H.D. Ohr, N.M. Grech, M.E. McGiffen, Jr., and J.J. Sims. 1998. Evaluation of methyl iodide as a soil fumigant in container and small field plot studies. Pestic. Sci. 52:58-62.

Browne, G., H. Becherer, S. McLaughlin, S. Fennimore, J. Duniway, F. Martin, H. Ajwa, C. Winterbottom, and L. Guererro. 2003a. Integrated management of Phytophthora on strawberry without methyl bromide, p. 128-1-128-2. In: Proc. Annu. Intl. Res. Conf. on Methyl Bromide Alternatives and Emissions Reductions, 3-6 Nov. 2003, San Diego, CA. 15 July 2008. $<$ http://www.mbao.org/2003/mbrpro03.html $>$.

Browne, G., J. Connell, H. Becherer, S. McLaughlin, S. Schneider, S. Lee, and E. Hosoda. 2003b. Evaluation of rootstocks and fumigants for control of almond replant disease, p. 11-1-11-2. In: Proc. Annu. Intl. Res. Conf. on Methyl Bromide Alternatives and Emissions Reductions, 3-6 Nov. 2003, San Diego, CA. 15 July 2008. $<$ http://www.mbao.org/2003/mbrpro03.html $>$.

California Dept. of Food and Agriculture. 2002. Approved treatment and handling procedures to ensure against nematode pest infestation of nursery stock. Nursery inspection procedures manual, Item \#7.

De Cal, A., A. Martinez-Treceno, J.M. LopezAranda, and P. Melgarejo. 2004. Chemical alternatives to methyl bromide in Spanish strawberry nurseries. Plant Dis. 88:210-214.

Eayre, C.G., J.J. Sims, H.D. Ohr, and B. Mackey. 2000. Evaluation of methyl iodide for control of peach replant disorder. Plant Dis. 84:1177-1179.

Fennimore, S.A., M.J. Harr, and H.A. Ajwa. 2003. Weed control in strawberry provided by shankand drip-applied methyl bromide alternative fumigants. HortScience 38:55-61.

Flegg, F.F.M. and D.F. Hooper. 1970. Extraction of free-living stages from soil, p. 5-22. In: Southey, J.F. (ed.). Laboratory methods for work with plant and soil nematodes. Technical Bulletin 2. Ministry of Agriculture, Fish and Food, London, UK.

Gamliel, A., A. Grinstein, Y. Peretz, L. Klein, A. Nachmias, L. Tsror, L. Livescu, and J. Katan. 1997. Reduced dosage of methyl bromide for controlling Verticillium wilt of potato in experimental and commercial plots. Plant Dis. 81:469-474.

Gan, J., S.K. Papiernik, S.R. Yates, and W.A. Jury. 1999. Temperature and moisture effects of fumigant degradation in soil. J. Environ. Qual. 28:1436-1441.

Gan, J., S.R. Yates, D. Wang, and F.F. Ernst. 1998. Effect of application methods on 1,3-dichloropropene volatilization from soil under controlled conditions. J. Environ. Qual. 27:432-438.

Gerik, J.S. 2005. Evaluation of soil fumigants applied by drip irrigation for Liatris production. Plant Dis. 89:883-887.

Gilreath, J., B. Santos, T. Motis, J. Noling, and J. Mirusso. 2005. Methyl bromide alternatives for nematode and Cyperus control in bell pepper (Capsicum annuum). Crop Prot. 24:903-908.

Hutchinson, C.M., M.E. McGiffen, Jr., H.D. Ohr, J.J. Sims, and J.O. Becker. 1999. Evaluation of methyl iodide as a soil fumigant for root-knot nematode control in carrot production. Plant Dis. 83:33-36.

Hutchinson, C.M., M.E. McGiffen, Jr., J.J. Sims, and J.O. Becker. 2004. Fumigant combinations for Cyperus esculentum L control. Pest Mgt. Sci. 60:369-374.

Karlik, J.F., J.O. Becker, and U.K. Schuch. 2001. IPM for field-grown rose plants in California. Acta Hort. 547:97-102.

Mann, R., S. Mattner, R. Gounder, R. Brett, and I. Porter. 2005. Evaluating novel soil fumigants for Australian horticulture, p. 34-1-34-4. In: Proc. Annu. Intl. Res. Conf. on Methyl Bromide Alternatives and Emissions Reductions, 31 Oct.-3 Nov. 2005, San Diego, CA.15 July 2008. $<$ http://www.mbao.org/2005/05Proceedings/ mbrpro05.html>.

McKenry, M.V., D. Buessing, and K. Williams. 2003. New chisel shanks enable improved fumigation of finer-textured soils, p. 36-1-36-3. In: Proc. Annu. Intl. Res. Conf. on Methyl Bromide Alternatives and Emissions Reductions, 3-6 Nov. 2003, San Diego, CA.15 July 2008. $<$ http://www.mbao.org/2003/mbrpro03.html>.

McKenry, M.V. and I.J. Thomason. 1974. 1,3dichloropropene and 1,2-dibromoethane compounds: II. Organism-dosage-response studies in the laboratory with several nematodes species. Hilgardia. A Journal of Agricultural Science Published by the California Agricultural Experiment Station 42:422-438.

McKenry, M.V. and I.J. Thomason. 1976. Dosage values obtained following pre-plant fumigation for perennials. I. 1,3-dichloropropene nematocides in eleven field situations. Pestic. Sci. 7: 521-534.

Munnecke, D.E. and S.D. Van Gundy. 1979. Movement of fumigants in soil, dosage responses, and differential effects. Annu. Rev. Phytopathol. 17:405-429.

Noe, J.P. 1985. Analysis and interpretations of data from nematological experiments, p. 187-196. In: Barker, K.R., C.C Carter, and J.N. Sasser (eds.). An advanced treatise on Meloidogyne. Vol. 2: Methodology. North Carolina State University Graphics, Raleigh, NC.

Ohr, H.D., J.J. Sims, N.M. Grech, J.O. Becker,and M.E. McGiffen, Jr. 1996. Methyl iodide, an ozone-safe alternative for methyl bromide as a soil fumigant. Plant Dis. 80:731-735.

Overman, A.J. 1982. Soil fumigation via drip irrigation under full-bed mulch culture for row crops. Proc. Soil and Crop Sci. Soc. Florida 41:153-155.

Overman, A.J., A.A. Csizinszky, J.P. Jones, and C.D. Stanley. 1987. Efficacy of metam sodium applied via drip irrigation on tomato. Proc. Soil and Crop Sci. Soc. Florida 46:4-7.

Roberts, P.A., A.C. Magyuarosy, W.C. Matthews, and D.M. May. 1988. Effects of metam-sodium applied by drip irrigation on root-knot nematodes, Pythium ultimum, and Fusarium spp. in soil and on carrot and tomato roots. Plant Dis. 72:213-217.

Rodriguez-Kabana, R. 2005. Herbicidal and nematicidal properties of drench applications of furfural (2-fururaldehyde), p. 19-1. In: Proc. Annu. Intl. Res. Conf. on Methyl Bromide Alternatives and Emissions Reductions, 31 Oct.-3 Nov. 2005, San Diego, CA. 15 July 2008. <http://www.mbao. org/2005/05Proceedings/mbrpro05.html >.

Rodriguez-Kabana, R., L. Simmons, R.H. Walker, and J.L. Belcher. 2005. Combinations of sodium azide and commercially available herbicides for weed control. Annu. Intl. Res. Conf. on Methyl Bromide Alternatives and Emissions Reductions p. 19-1.

SAS Institute Inc. 1985 SAS/STAT guide for personal computers, version 6 edition. Cary, $\mathrm{NC}$.

Schneider, R.C., R.E. Green, J.D. Wolt, R.K.H Loh, D.P. Schmitt, and B.S. Sipes. 1995. 1,3dichloropropene distribution in soil when applied by drip irrigation or injection in pineapple culture. Pestic. Sci. 43:97-105.

Schneider, S.M., H. Ajwa, T. Trout, G. Browne, and J. Sims. 2005. Field evaluations of methyl bromide alternatives for vineyard replant, $\mathrm{p}$. 45-1-45-6. In: Annu. Intl. Res. Conf. on Methyl Bromide Alternatives and Emissions Reductions, 31 Oct.-3 Nov. 2005, San Diego, CA. 15 July 2008. <http://www.mbao.org/ 2005/05Proceedings/mbrpro05.html $>$.

Schneider, S.M., H. Ajwa, T. Trout, and J. Sims. 2001. Field evaluation of nematode control alternatives for grapevine nurseries, p. 76-1-764. In: Annu. Intl. Res. Conf. on Methyl Bromide Alternatives and Emissions Reductions, 5-9 Nov. 2001, San Diego, CA. 15 July 2008. <http://www. mbao.org/2001proc/mbrpro01.html $>$.

Stanghellini, M.E., D.M. Ferrin, D.H. Kim, M.M. Waugh, K.C. Radewald, J.J. Sims, and H.D. Ohr. 2003. Application of preplant fumigants via drip irrigation systems for the management of root rot of melons caused by Monosporascus cannonballus. Plant Dis. 87: 1176-1178.

U.S. Environmental Protection Agency. 2008. Ozone depletion rules \& regulations. 15 May 2008. $<$ http://www.epa.gov/cgi-bin/epaprintonly.cgi>.

U.S. Patent Office. 1957. Method and composition for the treatment of soil. Patent No. 2,794,727. Patented 4 June 1957.

Waggoner, M., H.D. Ohr, C. Adams, J.J. Sims, and D. Gonzalez. 2000. Methyl iodide: An alternative to methyl bromide for insectary fumigation. J. Appl. Entomol. 124:113-117.

Westerdahl, B., D. Giraud, S. Etter, L.J. Riddle, J.D. Radewald, C.A. Anderson, and J. Darso. 2003. Management options for Pratylenchus penetrans in Easter lily. J. Nematol. 35:443449.

Westerdahl, B.B., D. Giraud, J.D. Radewald, C.A. Anderson, and J. Darso. 1993. Management of Pratylenchus penetrans on oriental lilies with drip and foliar-applied nematocides. Suppl. J. Nematol. 25:758-767.

Xue, S.K., J. Gan, S.R. Yates, and J.O. Becker. 2000. Nematode response to methyl bromide and 1,3-dichloropropene soil fumigation at different temperatures. Pest Mgt. Sci. 56:737742.

Yates, S.R. and J. Gan. 1997. Propargyl bromide-A possible chemical alternative to methyl bromide for pre-plant soil fumigation, p. 42-142-3. In: Proc. Annu. Intl. Res. Conf. on Methyl Bromide Alternatives and Emissions Reductions, 3-5 Nov. 1997, San Diego, CA. 15 July 2008. <http://www.mbao.org/mbrpro97.html>

Zasada, I.A., H. Ferris, C.L. Elmore, J.A. Roncoroni, J.D. MacDonald, L.R. Bolkan, and L.E. Yakabe. 2003. Field application of brassicaceous amendments for control of soilborne pests and pathogens. Plant Health Progress. 15 July 2008. <http://www.plantmanagementnetwork. org/pub/php/research/2003/amend/>.

Zhang, W.M., M.E. McGiffen, Jr., J.O. Becker, H.D. Ohr, J.J. Sims, and R.L. Kallenback. 1997. Dose response of weeds to methyl iodide and methyl bromide. Weed Res. 37:181-189. 